\title{
Comparative study of erythrocyte morphology and size in relation to ecophysiological adaptations in Rodentia species
}

\author{
Aleksandra G. Kizhina*, Svetlana N. Kalinina, Lyudmila B. Uzenbaeva, \\ Danila V. Panchenko, Stanisław Kapiński, Victor A. Ilyukha, \\ Elvira F. Pechorina \& Vlada O. Fokina
}

\begin{abstract}
The size of erythrocytes varies widely across mammals. Previously, deviations from allometric relationships and existence of factors regulating erythrocyte size other than body mass have been shown. The contribution of factors such as habitat and taxonomy are still under discussion. In the present study we examined the morphology of erythrocytes in rodent species and determined their diameter, and for Ondatra zibethicus and Sciurus vulgaris this was done for the first time. We discovered that erythrocyte diameter of the investigated rodent species ranged from 5.5 to $8.4 \mu \mathrm{m}$, varying by a factor of more than 1.5 . We analyzed our own data obtained for 10 species as well as data from the literature for 22 species. We found that the size of erythrocytes depended on the phylogenetic position, environmental conditions and body mass.
\end{abstract}

How to cite this article: Kizhina A.G., Kalinina S.N., Uzenbaeva L.B., Panchenko D.V., Łapiński S., Ilyukha V.A., Pechorina E.F., Fokina V.O. 2020. Comparative study of erythrocyte morphology and size in relation to ecophysiological adaptations in Rodentia species // Russian J. Theriol. Vol.19. No.2. P.161-171. doi: 10.15298/rusjtheriol.19.2.06.

KEY WORDS: erythrocytes, adaptations, rodents, ecological physiology, morphometry.

Aleksandra G. Kizhina [golubewa81@yandex.ru], Institute of Biology, Karelian Research Centre, Russian Academy of Sciences, Pushkinskaya str. 11, Petrozavodsk 185910, Russia, Petrozavodsk State University, pr. Lenina 33, Petrozavodsk 185000, Russia; Svetlana N. Kalinina [cvetnick@yandex.ru], Institute of Biology, Karelian Research Centre, Russian Academy of Sciences, Pushkinskaya str. 11, Petrozavodsk 185910, Russia, Petrozavodsk State University, pr. Lenina 33, Petrozavodsk 185000,Russia; Lyudmila B. Uzenbaeva [lyudmila.uzenbaeva@yandex.ru], Institute of Biology, Karelian Research Centre, Russian Academy of Sciences, Pushkinskaya str. 11, Petrozavodsk 185910, Russia; Danila V. Panchenko [danja@inbox.ru], Institute of Biology, Karelian Research Centre, Russian Academy of Sciences, Pushkinskaya str. 11, Petrozavodsk 185910, Russia; StanistawLapiński [stanislaw.lapinski@urk.edu.pl],University of Agriculture in Krakow, Department of Poultry and Animal Breeding and Animal Hygiene, 21 Al. Mickiewicza, 31-120, Kraków, Poland; Victor A. Ilyukha [ilyukha.62@mail.ru], Institute of Biology, Karelian Research Centre, Russian Academy of Sciences, Pushkinskaya str. 11, Petrozavodsk 185910,Russia; Elvira F.Pechorina [elvi1955@yandex.ru], Institute of Biology, Karelian Research Centre, Russian Academy of Sciences, Pushkinskaya str. 11, Petrozavodsk 185910, Russia; Vlada O. Fokina [v.fokina45vf@icloud.com], Institute of Biology, Karelian Research Centre, Russian Academy of Sciences, Pushkinskaya str. 11, Petrozavodsk 185910, Russia, Petrozavodsk State University, pr. Lenina 33, Petrozavodsk 185000, Russia.

\section{Сравнительное исследование морфологии и размеров эритроцитов в экофизиологических адаптациях у видов отряда Rodentia}

\section{А.Г. Кижина*, С.Н. Калинина, Л.Б. Узенбаева, Д.В. Панченко, С. Лапински, В.А. Илюха, Э.Ф. Печорина, В.О. Фокина}

РЕЗЮМЕ. Размер эритроцитов широко варьирует среди млекопитающих. Ранее обсуждались некоторые противоречия, касающихся аллометрических зависимостей, а также факторы, регулирующие размер эритроцитов, помимо массы тела. Влияние таких факторов, как среда обитания и таксономическое положение на величину эритроцитов все еще остаются предметом обсуждений. В настоящем исследовании мы изучили морфологию эритроцитов грызунов и определили их диаметр, причем для Ondatra zibethicus и Sciurus vulgaris это было сделано впервые. Диаметр эритроцитов у исследованных видов грызунов варьирует от 5.5 до 8.4 мкм, что составляет более чем 1.5 раза. Многофакторный

* Corresponding author 
анализ собственных данных (10 видов) и сведений из литературы (22 вида) о диаметре эритроцитов грызунов показал, что величина клеток зависит от размера животного, образа жизни вида и определяется его таксономическим положением.

КЛЮЧЕВЫЕ СЛОВА: эритроциты, адаптации, грызуны, экологическая физиология, морфометрия.

\section{Introduction}

Living in a wide variety of environments (at different depths and elevations, in warm or cold climatic conditions), an organism adapts to the habitat by adjusting its physiological traits, including the oxygen transport system. Mammalian erythrocytes, or red blood cells (RBC), are the most common type of blood cells, which have lost the nucleus and mitochondria in the course of evolution. Being essential for tissue oxygenation, erythrocytes take part in its regulation by changing their count, size, morphology, hematocrit, hemoglobin $(\mathrm{Hb})$ concentration, and oxygen affinity.

The erythrocyte size is a stable species-specific characteristic which was formed evolutionarily (Ruiz et al., 2004). Across mammalian species, erythrocytes vary in size and shape, and these parameters can define the architecture of the circulatory system, namely capillary diameter (Starostová et al., 2013). In general, mammalian erythrocytes exhibit morphological homogeneity. Erythrocytes in mammals are typically shaped as radially symmetrical, bulging biconcave disks, deformable, and high in surface to volume ratio, except in Camelidae, who have oval / ellipsoidal cells. This shape allows camelids to adapt during drastic dehydration. The bilaminar oval also helps in hypoxic high altitude habitats (Long, 2007). It has been noted that mammalian species vary in erythrocyte thickness; thus, humans and the European rabbit (Oryctolagus cuniculus L., 1758) have thicker erythrocytes while the common vole (Microtus arvalis Pallas, 1778) has much thinner cells (Kostelecka-Myrcha, 1966; Campbell, 2004; Turgeon, 2004).

According to previously presented data, mammalian erythrocyte diameter may vary more than five-fold, ranging from $2.1 \mu \mathrm{m}$ in the Java mouse-deer (Tragulus javanicus Osbeck, 1765) to $10.8 \mu \mathrm{m}$ in the Northern elephant seal (Mirounga angustirostris Gill, 1866) (Gregory, 2005). Despite the large amount of data on RBC size in mammalian species, the reasons for such pronounced variation are still being discussed (Promislow, 1991; Benga et al, 1992; Gregory, 2000; Unruh, 2018).

Body size-related differences in erythrocyte size in mammals have been widely examined (Kostelecka-Myrcha, 1973, 2002; Promislow, 1991). Common patterns, such as dependence of erythrocyte size on body mass, have been detected for 54 species of mammals belonging to 10 orders and having different weight (Kostelecka-Myrcha, 2002). The information concerning the influence of environmental, behavioral and life history factors on the erythrocyte size seems ambiguous.

$\mathrm{McNab}$ (2008) established a relationship between the basal metabolic rate in mammalian species and such factor as characteristics of the diet and habitat. In the study of Marsupial species no significant differences in erythrocyte sizes were detected despite marked differences in diet and habitat (Benga et al., 1992). Unruh (2018) speculated on the role of the diet type and the related water intake on erythrocyte diameter. Similar values of the size of erythrocytes were found in hares (Lagomorpha) and Carnivores, and, on the contrary, significant differences were demonstrated between members of Artiodactyla and Primates, many of which are herbivores (Promislow, 1991).

It has been shown that rodents' hematological characteristics may be influenced by ambient temperature, burrowing, elevation or diving hypoxia (Wei \& Wei, 2001; Frase, 2002; Thomas \& Ono, 2015; Bottaeva et al., 2019). Schmidt-Nielsen and Knut (1984) explained the relatively high values of RBC volume in pinnipeds (Pinnipedia) by adaptation to hypoxia during prolonged immersion. At the same time, the volume of erythrocytes in dolphins (Delphinidae) does not significantly differ from that in humans, dogs (Canis familiaris L., 1758) or jackals (C. aureus L., 1758) (Galantsev, 1977). Mammals adapted to hypoxia at high altitudes or through burrowing differ from diving mammals in blood respiratory characteristics (higher $\mathrm{HbO}_{2}$ affinity) (Bullard et al., 1966). Among burrowers, there is neither a dramatic increase in mean cell volume (MCV) such as occurs in diving mammals, nor a decrease in MCV as exists in certain high-altitude natives (Lechner, 1976).

According to the latest reports, the erythrocyte size is phenotypically plastic and significantly affected by temperature and season (Tarakhtii \& Davydova, 2007; Goodman \& Heah, 2010). On the other hand, some authors advocate the idea of a genetically predetermined erythrocyte size annual variation, occurring independently of acclimatization, and appearing in response to photoperiodic stimuli (Ruiz et al., 2004).

Rodents are the largest group of known mammalian species; they have a wide geographic distribution from the Arctic to deserts. There are many morphological and ecological differences among them, including variations in size, weight and habitat. Studies of rodent erythrocytes are of wide interest in relation to the influence of various environmental factors on the morphology and profile of blood. However, the currently available information about the hematological parameters and the morphological features of erythrocytes in some species of rodents, for example, red squirrel, chinchilla, muskrat, is insufficient and contradictory. Moreover, no comparative analysis of erythrocyte sizes among rodent species has been carried out so far. 
We hypothesize that differences in erythrocyte size across rodent species result from a balanced interplay of various environmental and physiological factors. The aims of this study were to: 1) study erythrocyte morphology by light microscopy and determine erythrocyte diameter in 10 rodent species; 2) determine the contribution of environmental, phylogenetic and physiological factors to erythrocyte size variation using all the available information on erythrocyte diameter in rodents ( 22 species).

\section{Material and methods}

All the experiments were conducted according to EU guidelines on the use of animals for biochemical research $(86 / 609 / \mathrm{EU})$ with special permission from the Local Ethics Committee of the Institute of Biology. The research was performed using the equipment of the Core Facility of the Karelian Research Centre of the Russian Academy of Sciences.

\section{Studied animals}

We investigated wild (North American beaver Castor canadensis Kuhl, 1820, muskrat Ondatra zibethicus L., 1766, red squirrel Sciurus vulgaris L., 1758, European water vole Arvicola amphibius L., 1758, bank vole Myodes glareolus Schreber, 1780), farmed (nutria Myocastor coypus Molina, 1782 and chinchilla Chinchilla lanigera Bennett, 1829), and laboratory (rat Rattus norvegicus Berkenhout, 1769, golden hamster Mesocricetus auratus Waterhouse, 1839, and mouse Mus musculus L., 1758) animals. All the studied animals were adults.

Blood samples were obtained from beavers, muskrats and squirrels taken during the hunting seasons of 2011 and 2015 with permits from the Game Management Directorate of the Republic of Karelia, Russia (permit numbers: 000002-2011, 000001-2011 and 00008-2015). European water voles and bank voles were captured with pitfall traps, after which the animals were sacrificed by displacing vertebrae. The voles captured for this study are not included in the list of licensed and protected species. All the wild animals used in the study inhabit Northern European Russia (Karelia). Blood samples of wild rodents were obtained in August-September. Blood was collected by cardiac puncture at the time the animals were killed (post mortem).

The nutrias and chinchillas were of a standard breed and kept at a fur farm in Poland (Permission No. 32/2010, First Local Ethical Committee on Animal Testing at the Jagiellonian University in Krakow). Nutrias were kept in cages with water reservoirs, under conventional feeding consisting of a clover-grass mixture with grain supplement. Chinchillas were fed with pelleted food and provided with clean drinking water ad libitum. Nutrias and chinchillas were immobilized; blood samples were taken from the coccygeal vein and claw vessel, respectively. Blood sampling was performed in summer season. Adult and healthy Wistar rats, C57/BL6 mice and golden hamsters were bred in a laboratory under constant temperature and light conditions. The animals were kept in standard cages with food and water provided ad libitum. Blood was collected from the animals following decapitation.

Seasonal changes in hematological parameters, including erythrocyte size, should be expected when comparing samples taken in seasons with different temperature and light conditions and availability of food resources. Small and short-lived erythrocytes appear under the trying conditions of the autumn-winter period (Tarakhtii \& Davydova, 2007). The fact that blood sampling in wild animals was done when the climatic conditions were relativity mild and constant, while the laboratory and farmed animals were bred under standard conditions is sufficient reason to ignore the seasonal factor.

We also analyzed data on 22 Rodentia species (Cricetidae, Dipodidae, Muridae, Sciuridae, Erethizontidae, Hystricidae, Chinchillildae, Myocastoridae, Castoridae and Caviidae) obtained from various sources (Tab. 1).

Body mass in laboratory and farmed species was measured by authors themselves; data for wild species were obtained from Drożdż et al. (1971), Segal (1978), MacArthur (1984), and Wauters (2007). Body mass data for species additionally included in the analysis were obtained from the following sources: Foreman (1956), Kostelecka-Myrcha (1966), Moore (1966), Kostelecka-Myrcha (1967), Bolls \& Perfect (1972), Bozinovic \& Rosenmann (1988), Sabanova (2010), Lantová et al. (2011), Bottaeva (2017) and Bottaeva et al. (2019).

\section{Light microscopy and erythrocyte mor-} phometry

Blood smears were made immediately after blood collection. Thin blood smears were allowed to air dry and then stained with May-Grünwald and Romanowski stains (MiniMed, Russia). Each smear was examined for cell morphology with light microscope (Axioscop 40, Zeiss, Germany) under oil immersion with $100 \times$ objective lens. We considered the presence/absence and frequency of occurrence of polychromatophilic erythrocytes, normoblasts and Howell-Jolly bodies (H-J bodies). Photomicrographs were obtained, transferred to computer, and captured with the help of image software VideoTest 4.0 (Video Test Inc., Russia). To determine the diameter of erythrocytes, we analyzed 10-20 fields of view (more than 50 cells per field of view) from each blood smear. Only clear fields of view with adequate morphology of erythrocytes were examined. The diameter of erythrocytes was measured automatically by the NCR (nuclear-cell ratio) method using image software.

\section{Statistical analysis}

Mean erythrocyte diameters of 10 rodent species were calculated. These data were pooled together with data for 22 species from the literature in Table 1.

Based on McNab's classification (McNab, 2008), the 32 species were analyzed according to their habitat affiliations (desert, freshwater, mesic and xeric) with some modifications. 


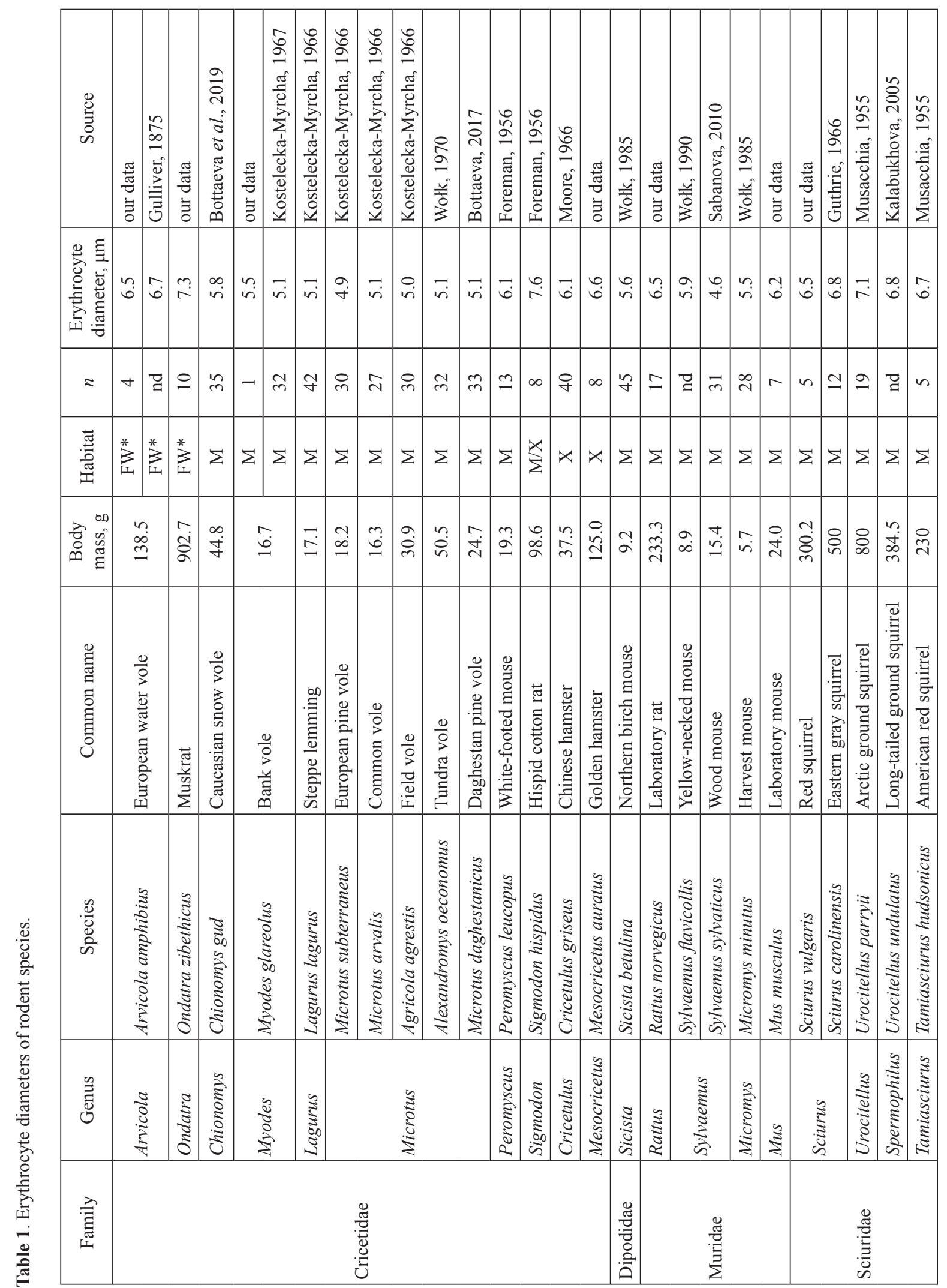


范

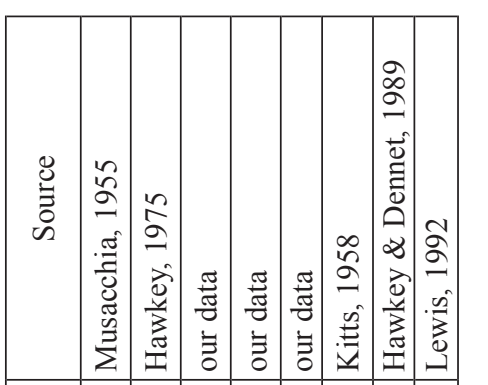

을

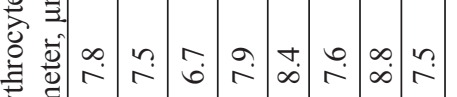
空

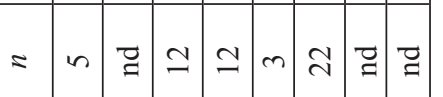

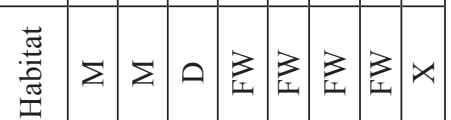

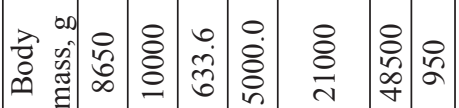

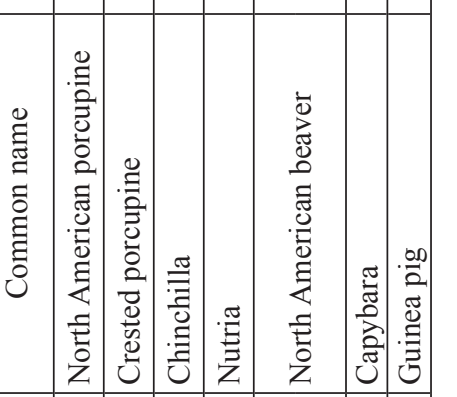

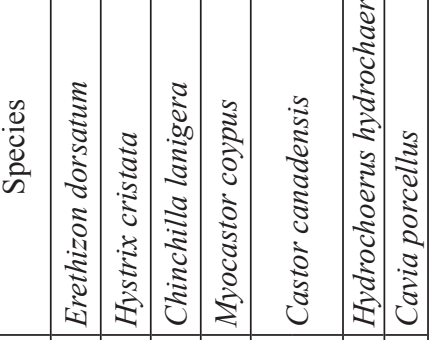

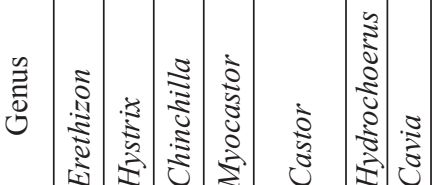

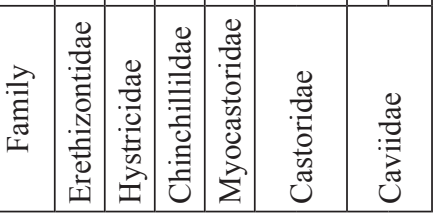

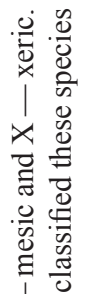

$\sum_{i=1}^{1} \sum_{0}^{\infty}$

荧

孪旁

3 인

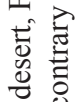

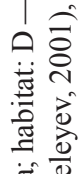

卷

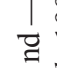

范

衰兴

牙

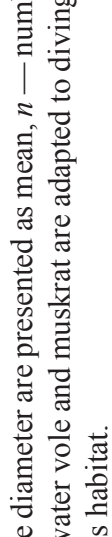

उ 3

월

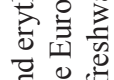

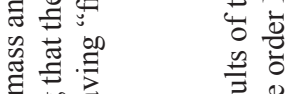
고을 它.

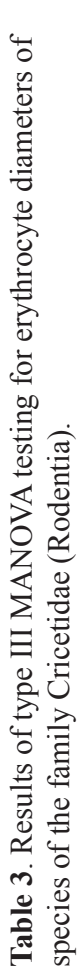

\begin{tabular}{|c|c|c|c|}
\hline $\begin{array}{l}\frac{0}{\pi} \\
\frac{\pi}{2} \\
2\end{array}$ & 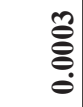 & $\frac{\bar{g}}{\stackrel{J}{0}}$ & $\begin{array}{l}\infty \\
\stackrel{0}{0} \\
\stackrel{0}{0}\end{array}$ \\
\hline 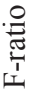 & $\begin{array}{l}0 \\
\circ \\
n\end{array}$ & $\stackrel{0}{\stackrel{0}{0}}$ & $\begin{array}{c}\widetilde{\alpha} \\
\infty\end{array}$ \\
\hline 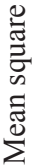 & 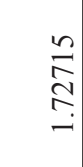 & $\begin{array}{l}\infty \\
\infty \\
\\
\equiv \\
0 \\
0\end{array}$ & 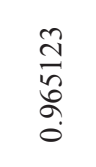 \\
\hline ఝ̈. & - & - & $\sim$ \\
\hline $\begin{array}{l}{ }^{\circ} \\
\stackrel{2}{*}\end{array}$ & త్ర. & 1 & $\stackrel{\infty}{\stackrel{\infty}{r}}$ \\
\hline 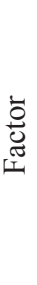 & 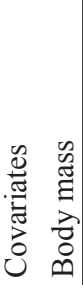 & 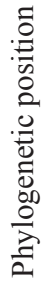 & 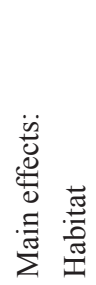 \\
\hline
\end{tabular}
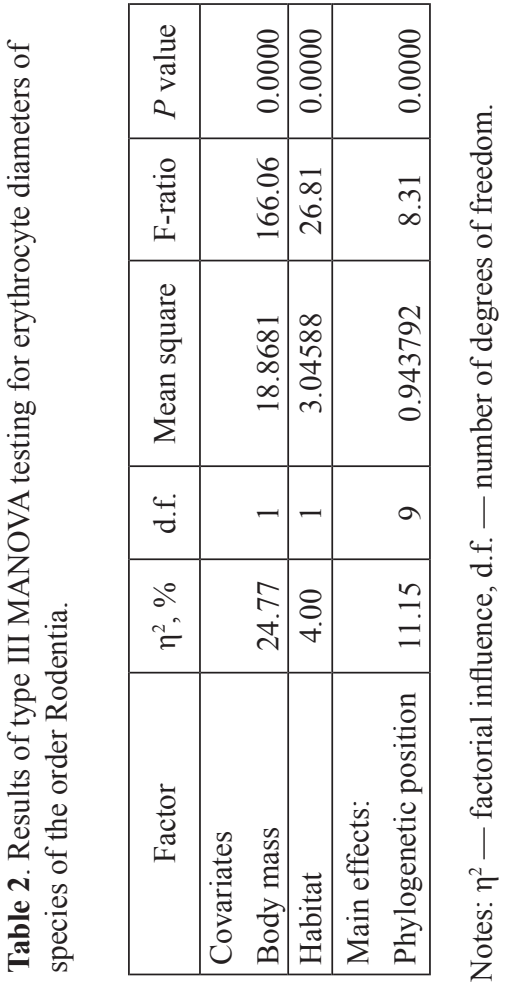
Body mass of Rodentia species ranged from 5.7 to $48500 \mathrm{~g}$. All the species were clustered into 17 groups according to their average body mass. The amplitude of body mass variation among species within a group did not exceed $26 \%$.

To assess the effect of the phylogenetic factor (family/genus) we conducted a type III MANOVA (multiple analysis of variance) without intercept testing of Rodentia erythrocyte size using erythrocyte diameter as the dependent variable, phylogenetic position as the main factor, habitat and body mass as covariates due to correlation with the main factor (Tab. 2). Type III MANOVA testing of Cricetidae (Rodentia) erythrocyte size was performed with erythrocyte diameter as the dependent variable, habitat as the main factor, phylogenetic position and body mass as covariates due to correlation with the main factor (Tab. 3).

The statistical analysis was performed using MS Excel software (Microsoft Corp., Inc., USA) and Stat Graphics Version 5.0 (Statistical Graphics Corp., USA).

\section{Results}

\section{Erythrocyte morphology}

The erythrocyte morphology of the studied species is shown in Figure 1. In all 10 species, erythrocytes were usually round, anucleated, red cells. The RBC size
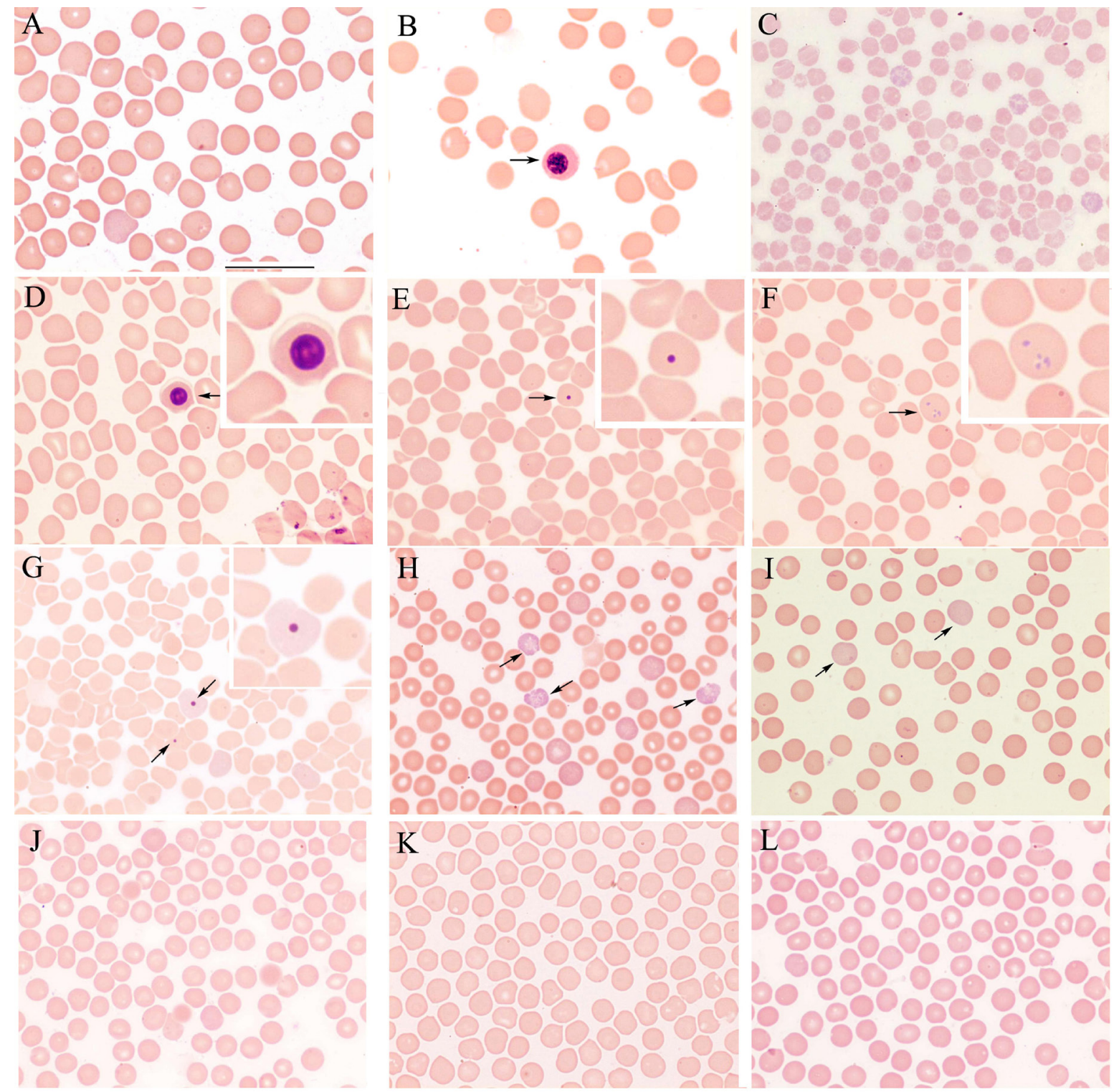

Fig. 1. Erythrocytes in rodents' blood smears. A, B - North American beaver, C - bank vole; D - nutria; E, F - muskrat, $\mathrm{G}$ - mouse; H - European water vole, I - rat; J - red squirrel, $\mathrm{K}$ - chinchilla, L — hamster. Note: arrow - normoblast in beaver (B) and nutria (D), Howell-Jolly body in muskrat (E) and mouse (G), basophilic stippling in muskrat (F). Bar $=25 \mu \mathrm{m}$. Stained with May-Grünwald, Romanowsky. 
variation and specific features of erythrocyte morphology were seen in peripheral blood smears. The largest erythrocytes were found in the North American beaver (Figs 1A-B). Nutria also had quite large cells. The smallest size of erythrocytes was detected for the bank vole (Fig. 1C). Other species had similar erythrocyte sizes (Figs 1E-K).

Normoblasts or nucleated erythroid cells (Fig. 1D) were occasionally present in the circulating blood of semi-aquatic mammals - beavers, nutria, muskrat, and European water vole. A majority of erythrocytes in diving animals had no central pallor.

H-J bodies are homogeneous, dark purple spherical structures, which are nuclear remnants (Figs 1E-F). H-J bodies were present in the peripheral blood of nutria, muskrat, bank vole, and mouse. H-J bodies in mice were notably larger than in other species (Fig. 1F).

Polychromatophils are young, anucleated erythrocytes. These cells appear gray or bluish-red with May-Grünwald and Romanowski stains. These cells were present in most of the studied species - muskrat, rat, mouse, red squirrel, bank vole, and European water vole (Figs 1G-H). However, polychromatophilic erythrocytes were more common in muskrat, rat, mouse, bank vole, and European water vole than in red squirrel, and were absent in chinchilla and hamster (Figs $1 \mathrm{~J}-\mathrm{K}$ ).

Basophilic stippling in erythrocytes appears as multiple fine blue dots in the cytoplasm of erythrocytes. This morphologic feature was sometimes seen in muskrat (Fig. 1L) and bank vole.

\section{Erythrocyte morphometry}

The results of the morphometric analysis of erythrocytes in rodent species are illustrated in Table 1. It has been shown through a comparative analysis of our own and previously known data that the largest forms of red blood cells are characteristic of divers with body mass over $4 \mathrm{~kg}$ - beaver, nutria, and capybara (Hydrochoerus hydrochaeris L., 1766). The smallest surface area and diameter were revealed among Sylvaemus, Microtus, and Myodes.

MANOVA revealed a significant influence of habitat, body mass and phylogeny factors on erythrocyte diameter across the order Rodentia (Tab. 2). The influence of body mass and environment on cell size was confirmed also at a lower taxonomic level (family), although the effect was less pronounced (Tab. 3).

\section{Discussion}

Our results showed differences in erythrocyte size and morphology to exist among rodent species. The largest erythrocyte size was observed in such semi-aquatic animals as beavers and nutria. Previous studies demonstrated that the volume of erythrocytes in the Eurasian and North American beavers was almost double that of non-aquatic rodents (Patenaude \& Genest, 1977; Girling et al., 2015). Mean erythrocyte diameter in the nutria in the present study $(7.84 \mu \mathrm{m})$ was similar to the finding of Jelínek (1984) $(7.4 \mu \mathrm{m})$. Diving marine and semi-aquatic mammals need greater amounts of oxygen. Canfield (1998) reported that erythrocytes in diving mammals may have no central pallor because they are thicker cells, as adaptation for slow release of oxygen. Large erythrocyte size is a useful adaptation allowing a higher concentration of $\mathrm{Hb}$ per cell and an increase in blood oxygen-carrying capacity. It has been previously demonstrated that various marine mammals have large erythrocytes - manatee (Trichechus manatus L., 1758), dugong (Dugong dugon Müller, 1776), beluga whale (Delphinapterus leucas Pallas, 1774) (Harvey et al., 2009; Reiderson, 2010; Woolford et al., 2015). Their erythrocytes are comparable with those in elephants (Loxodonta africana Blumenbach, 1797), who have the largest erythrocytes among terrestrial mammals (Harr et al., 2010). The meaning of erythrocyte size for diving animals is indicated by the fact that MCV of the Harbor seal (Phoca vitulina L., 1758) is positively correlated with the maximum dive duration (Thomas \& Ono, 2015).

We found that semi-aquatic rodents were characterized by high occurrence of nucleated erythrocytes. Intensive erythropoiesis might explain the common occurrence of nucleated erythrocytes circulating in the peripheral blood (Harvey et al., 2009). We suppose that the presence of nucleated erythrocytes on blood smears in this animal group is a result of active erythropoiesis related to the demand for oxygen reserves in semi-aquatic animals.

This study demonstrated that the European water vole, a small freshwater diver, had the smallest erythrocytes among semi-aquatic rodents. However, the erythrocyte size of the European water vole (body mass $\sim 80 \mathrm{~g}$ ) was comparable to that of non-diving terrestrial mammals - squirrel, chinchilla, and rat (body mass $>$ $300 \mathrm{~g}$ ). The quite large size of erythrocytes in the European water vole can be considered as one of adaptations to semi-aquatic lifestyle. Another example supporting the role of habitat characteristics on RBC size is the fact that semi-aquatic muskrats have larger erythrocytes (78.43 fl) than terrestrial prairie dogs (Cynomys ludovicianus Ord, 1758) (62.00 fl) with similar body mass (Ahlers et al., 2011; Donnelly et al., 2015). It is obvious that the evolution of the respiratory function of blood in diving species did not follow an increase in the concentration of erythrocytes (Galantsev, 1977). This pattern is more typical of native high-elevation species and provides an enlarged diffusion area per unit volume of blood (Puchalski \& Heldmair, 1986). Furthermore, the erythrocyte size is one of the main determinants for the enhancement of platelet adherence (Aarts et al., 1983). This fact may be interesting in connection with the increased requirements of diving species for the coagulation system.

Previous studies have shown deviations from allometric relationships and existence of regulating factors other than body mass (Promislow, 1991). The mean diameter of bank vole erythrocytes was the smallest and differed from that of the mouse, whose body mass is similar $(\sim 20 \mathrm{~g})$. The erythrocyte size in hamsters is similar to that of rats, chinchillas and squirrels, whose body mass is much greater. Another deviation from the allometric 
model is hispid cotton rats (Sigmodon hispidus Say et Ord, 1825). Their erythrocyte size $(7.6 \mu \mathrm{m})$ is larger than would be predicted on the basis of weight. The higher $\mathrm{MCV}, \mathrm{Hb}$, and mean corpuscular hemoglobin values in hispid cotton rats compared to closely related species were noted in the study of Katahira \& Ohwada (1993). The authors point out that the physiological reason for this difference is not completely understood.

The MCV of erythrocytes in the capybara, the largest rodent, is $132 \mu \mathrm{m}^{3}$, i.e. $32 \%$ more than in beavers (Chiacchio et al., 2014; Girling et al., 2015). The erythrocyte diameter of the crested porcupine (Hystrix cristata L., 1758), third largest species among rodents after capybaras and beavers, is $7.5 \mu \mathrm{m}$ (Hawkey, 1975). Comparing this mean with our results, we see that porcupine's erythrocyte diameter is larger than in most of the rodents, but smaller than in the nutria. Promislow (1991) stated that "body mass is a highly significant predictor of blood physiology at lower taxonomic levels". This assertion can be corroborated by comparing erythrocyte sizes in species from different orders. The erythrocyte diameter of heavy carnivorous species - black bear (Ursus arctos L., 1758) and wolf (Canis lupus L., 1758) is smaller $(6.8 \mu \mathrm{m})$ (Gregory, 2000) than in some rodents with smaller body mass. Our analysis has demonstrated that at intermediate taxonomic levels (families within orders) body mass explained $24.77 \%$ of erythrocyte size variation. The influence of the body mass factor at a lower taxonomic level (species within family) decreased since the range of values was not so great.

Testing by MANOVA reveals that erythrocyte diameter depends on the family affiliation. However, no size differences were found between species of different genera within a family. A possible explanation is that closely related taxa formed from a common ancestor often have a similar ecology.

Our results revealed that terrestrial rodents' erythrocytes averaged 5.5 to $6.7 \mu \mathrm{m}$ in diameter, and are consistent with earlier reports (Wyckoff \& Frase, 1990; Frase, 2002; Heatley \& Harris, 2009). Free-living Murinae and Cricetidae are typically burrowing mammals adapting to hypoxia due to fossorial habit. A common trait for such animals (e.g. black-tailed prairie dog, Middle East blind mole-rat (Spalax ehrenbergi Nehring, 1898), Botta's pocket gopher (Thomomys bottae Eydoux et Gervais, 1836)) is high erythrocyte counts (MacArthur, 1984). It has been shown that burrowing rodents are characterized by high affinity for $\mathrm{O}_{2}$ and insensitivity to $\mathrm{CO}_{2}$ (Hall, 1966; Withers, 1978).

Previous studies indicated that the number of erythrocytes with $\mathrm{H}-\mathrm{J}$ bodies varied in mammalian species under natural conditions (Zúñiga et al., 1996). We noted that mice had a high occurrence of H-J bodies. Similarly, mice are characterized by the highest number of micronuclei in peripheral blood erythrocytes among rodents (RamírezMuñoz et al., 1999). In clinical and veterinary practice, counting of these fragments of erythrocyte nuclei is used for evaluating splenic function (Corazza et al., 1990). The number of erythrocytes containing $\mathrm{H}-\mathrm{J}$ bodies tends to increase in parallel with nucleated erythrocytes during regenerative anemia. Their occurrence at a high altitude $(1800 \mathrm{~m})$ was higher than at medium altitudes $(700 \mathrm{~m})$ (12.96\% vs. $3.12 \%$ ) (Yemkuzheva, 2013).

A physiological response to low $\mathrm{O}_{2}$ availability in high-altitude mammals is to increase the Hb concentration through higher RBC counts (Crait et al., 2012). It has been shown that erythrocyte diameter in the house mouse and the Ural field mouse (Sylvaemus uralensis Pallas, 1811) was smaller at a high altitude $(1000 \mathrm{~m})$ than at medium altitudes (500 and $700 \mathrm{~m}$ ) (Yemkuzheva, 2013). The chinchilla, who naturally resides at high altitudes, demonstrates smaller erythrocytes than would be predicted on the basis of weight. Smaller but more numerous red blood cells, high $\mathrm{Hb}$ values (Ederstrom et al., 1971), and high hemoglobin-oxygen affinities (Ostojic et al., 2002) in chinchillas accounted for their greater tolerance to hypoxia. Chinchillas have apparently retained their adaptations to altitude despite almost 100 years of domestication history. Another species native to high altitudes - the guinea pig, features larger erythrocytes and a lower RBC count than chinchillas (Siegel \& Walton, 2020). Both laboratory-type and wild-type guinea pigs, as well as chinchillas, have high hemoglobin-oxygen affinities. The cell size differences between chinchilla and guinea pig can be attributed to chinchilla's adaptation to xeric habitats. The increased blood plasma osmolality noted in some desert animals can be the reason that erythrocytes would lose water to the plasma and shrink (Urison \& Buffenstein, 1993).

We suppose that differences in degree of the influence body mass on the erythrocyte size depend on other endogenous and exogenous factors (e.g., ecology, blood chemistry, anatomic and physiological adaptations).

\section{Conclusions}

In summary, we comparatively analyzed the size of erythrocytes across rodent species. The erythrocyte morphology of two of the studied species - muskrat and red squirrel, is described for the first time. There was a general pattern of erythrocyte size increase with increasing body mass of species. MANOVA testing confirmed the existence of this common for rodent species pattern. Yet, the degree of body mass effect on erythrocyte size differs among taxonomic levels. We suppose there are some deviations from the allometric pattern. Other than body mass influence, the erythrocyte size can be analyzed in connection with ecological factors (habitat, lifestyle, locomotion activity etc.). According to MANOVA results, the largest size of erythrocytes in massive diving animals such as the capybara, beaver, and nutria is a result of the combined effect of semi-aquatic lifestyle and body mass. The relatively large RBCs of the European water vole can be considered as an adaptation to diving. We consider the presence of nucleated erythrocytes in blood of semi-aquatic rodents to be a result of active erythropoiesis related to high requirements for oxygen reserves. Thus, the lifestyle of rodent species affects the morphology and size of red blood cells. Further comparative studies with more species 
will expand our knowledge of the role of environmental factors in the respiratory function of blood. The results obtained can also be useful in environmental monitoring when studying the influence of anthropogenic factors on the parameters of the blood system and the state of the organism as a whole in species of the Rodentia order.

ACKNOWLEDGEMENTS. The work was supported by state order (project numbers 0218-2019-0073 and 0218-2019-0080). We are grateful to Dr. Ekaterina Antonova, Dr. Alina Yakimova, Dr. Evgeniy Khizhkin and Dr. Fyodor Fyodorov for their help and assistance with data collection. We also thank two anonymous reviewers whose comments on an earlier version of this manuscript greatly improved its quality. The authors are also grateful to Olga Kislova for improving the English text.

\section{References}

Aarts P.A., Bolhuis P.A., Sakariassen K.S., Heethaar R.M. \& Sixma J.J. 1983. Red blood cell size is important for adherence of blood platelets to artery subendothelium // Blood. Vol.62. P.214-217.

Ahlers A.A., Mitchell M.A., Schooley R.L., Heske E.J. \& Levengood J.M. 2011. Hematologic and blood chemistry reference values for free-ranging muskrats (Ondatra zibethicus) // Journal of Wildlife Diseases. Vol.47. P.685-689.

Baraquet M., Grenat P.R., Salas N.E. \& Martino A.L. 2013 Intraspecific variationin erythrocyte size among populations of Hypsiboas cordobae (Anura: Hylidae) // Acta Herpetologica. Vol.8. P.93-97.

Benga G., Porutiu D., Ghiran I., Kuchel P.W., Gallagher C.H. \& Cox G.C. 1992. Scanning electron microscopy of red blood cells from eleven species of marsupial // Comparative Haematology International. Vol.2. P.227-230.

Bolls N.J. \& Perfect J.R. 1972. Summer resting metabolic rate of the gray squirrel // Physiological Zoology. Vol.45. No.1. P.54-59.

Bottaeva Z.K. 2017. [Comparative characteristic of eritron of two species of vole under the conditions of the subalpical zone of the Tersky variant of zonality in the central Caucasus] // Izvestiya Samarskogo Nauchnogo Tsentra Rossiiskoi Akademii Nauk. Vol.19. No.5. P.30-35 [in Russian].

Bottaeva Z.K., Tembotova F.A., Emkuzheva M.M., Bersekova Z.A. \& Chapaev A.K. 2019. [Effect of ecogeographic factors along latitudinal-longitudinal gradient on the red blood system of the Caucasian snow vole (Chionomys gud), a species autochthonous to the Caucasus] // Ekologiya. Vol.50. P.34-42 [in Russian].

Bozinovic F. \& Rosenmann M. 1988. Comparative energetics of South American cricetid rodents // Comparative Biochemistry and Physiology. Vol.91A. P.195-202.

Bullard R.W., Broumand C. \& Meyer F.R. 1966. Blood characteristics and volume in two rodents native to high altitude // Journal of Applied Physiology. Vol.21. P.994-998.

Campbell T. 2015. Exotic animal hematology and cytology Hoboken, New Jersey: John Wiley \& Sons. 402 p.

Canfield P.J. 1998. Comparative cell morphology in the peripheral blood film from exotic and native animals // Australian Veterinary Journal. Vol.76. P.793-800.
Chiacchio R.G., Prioste F.E., Vanstreels R.E., Knobl T., Kolber M., Miyashiro S.I. \& Matushima E.R. 2014. Health Evaluation and Survey of Zoonotic Pathogens in Free-ranging Capybaras (Hydrochaeris hydrochaeris) // Journal of Wildlife Diseases. Vol.50. P.496-504.

Corazza G.R., Ginaldi L., Zoli G., Frisoni M., Lalli G., Gasbarrini G. \& Quaglino D. 1990. Howell-Jolly body counting as a measure of splenic function. A reassessment // Clinical Laboratory Hematology. Vol.12. P.269-275.

Crait J.R., Prange H.D., Marshall N.A., Harlow H.J., Cotton C.J. \& Ben-David M. 2012. High-altitude diving in river otters: coping with combined hypoxic stresses // Journal of Experimental Biology. Vol.215. No.2. P.256-263.

Donnelly T.M., Bergin I. \& Melanie I. 2015. Biology and diseases of other rodents // Fox J.G. (ed.). Laboratory Animal Medicine. Amsterdam etc: Academic Press. P.285-349.

Drożdż A., Górecki A., Grodziński W. \& Pelikán J. 1971. Bioenergetics of water voles (Arvicola terrestris L.) from southern Moravia // Annales Zoologici Fennici. Vol.8. P.97-103.

Ederstrom H.E., Akers T.K., Keefner K.R. \& Thompson R.E. 1971. Comparison of tolerance to hypoxia and hyperoxia in chinchillas and guinea pigs // Space Life Sciences. Vol.3. No.2. P.171-173.

Foreman C.W. 1956. Notes and blood data on some small mammals of Durham Country, North Carolina // Journal of Mammalogy. Vol.37. P.427-428.

Frase B.A. 2002. Hematological parameters of high-elevation bushy-tailed woodrats // The Southwestern Naturalist. Vol.47. P.508-510.

Galantsev V.P. 1977. [Anatomical and physiological adaptations of muskrat and European water vole to semi-aquatic life and diving] // Trudy Nauchno-issledovatel'skogo Sel'sko-khozyaistvennogo Instituta Krainego Severa. Vol.14. P.97-106 [in Russian].

Girling S.J., Campbell-Palmer R., Pizzi1 R., Fraser M.A., Cracknell J., Arnemo J. \& Rosell F. 2015. Haematology and serum biochemistry parameters and variations in the Eurasian beaver (Castor fiber) // PLoS ONE. Vol.10. No.6. $\mathrm{e} 0128775$.

Goodman R.M. \& Heah T.P. 2010. Temperature-induced plasticity at cellular and organismal levels in the lizard Anolis carolinensis // Integrative Zoology. Vol.5. P.208-217.

Gregory T.R. 2000. Nucleotypic effects without nuclei: Genome size and erythrocyte size in mammals // Genome. Vol.43. P.895-901.

Gregory T.R. 2005. Cell size database. http://www.genomesize. com/cellsize

Guthrie D.R., Mosby H.S. \& Osborne J.C. 1966. Hematological values for the eastern gray squirrel (Sciurus carolinensis) // Canadian Journal of Zoology. Vol.44. No.2. P.323-327.

Gulliver G. 1875. On the size and shape of red corpuscles of the blood of vertebrates, with drawings of them to a uniform scale, and extended and revised tables of measurement // Proceedings of the Zoological Society of London. P.474-495.

Hall F.G. 1966. Minimal utilizable oxygen and the oxygen dissociation curve of blood of rodents // Journal of Applied Physiology.Vol.21. P.375-378.

Harr K.E., Isaza R., Blue J.T., Weiss D.J. \& Wardrop K.J. 2010. Hematology of elephants // Weiss D.G. \& Wardrop K.J. 
(eds.) Schalm's Veterinary Hematology. Ames: Wiley-Blackwell. P.942-949.

Harvey J.W., Harr K.E., Murphy D., Walsh M.T., Nolan E.C., Bonde R.K., Pate M.G., Deutsch C.J., Edwards H.H. \& Clapp W.L. 2009. Hematology of healthy Florida manatees (Trichechus manatus) // Veterinary Clinical Pathology. Vol.38. P.183-193.

Hawkey C.M. 1975. Comparative Mammalian Haematology. London: Medical Books Ltd. 310 p.

Hawkey C.M. \& Dennet T.B. 1989. Comparative Veterinary Haematology. Ipswich: W.S. Cowell Ltd. 192 p.

Heatley J.J. \& Harris M.C. 2009. Hamsters and Gerbils // Mitchell M. \& Tully T.N. (eds.). Manual of Exotic Pet Practice. Elsevier. P.406-432.

Jelínek P. 1984. Basic hematological indices in adult nutria (Myocastor coypus M.) males // Acta Veterinaria Brno. Vol.53. P.41-47.

Kalabukhova T.N. 2005. [The evaluation of the size of erythrocytes of the hibernating ground squirrel Citellus undulatus Pallas] // Biofizika. Vol.50. No2. P.346-347 [in Russian].

Katahira K. \& Ohwada K. 1993. Hematological standard values in the cotton rat (Sigmodon hispidus) // Experimental Animals. Vol.42. No.4. P.653-656.

Kostelecka-Myrcha A. 1966. Hemoglobin, erythrocytes and hematocrit in the blood of some microtidae under laboratory conditions // Bulletin de l'Academie Polonaise des Sciences. Serie des Sciences Biologiques. Vol.14. P.343-349.

Kostelecka-Myrcha A. 1967. Variation of morpho-physiological indices of blood in Clethrionomys glareolus (Schreber, 1780) // Acta Theriologica. Vol.12. P.191-222.

Kostelecka-Myrcha A. 1973. Regularities of variations of the hematological values characterizing the respiratory function of blood in mammals // Acta Theriologica. Vol.18. P.1-6.

Kostelecka-Myrcha A. 2002. The ratio of amount of haemoglobin to total surface area of erythrocytes in mammals // Acta Theriologica. Vol.47. P.209-220.

Lantová P., Zub K., Koskela E., Šíchová K. \& Borowski Z. 2011. Is there a linkage between metabolism and personality in small mammals? The root vole (Microtus oeconomus) example // Physiology \& Behavior. Vol.104. No.3. P.378-383.

Lechner A.J. 1976. Respiratory adaptations in burrowing pocket gophers from sea level and high altitude // Journal of Applied Physiology. Vol.41. P.168-173.

Lewis J.H. 1992. Comparative hematology: studies on guinea pigs (Cavia porcellus) // Comparative Biochemistry and physiology. Part A: Comparative Physiology. Vol.102. No.3. P.507-512.

Long C.A. 2007. Evolution of function and form in camelid erythrocytes // Proceedings of the 2007 WSEAS Int. Conference on Cellular \& Molecular Biology - Biophysics \& Bioengineering. Athens, Greece, August 26-28, 2007. P.18-24.

MacArthur R.A. 1984. Seasonal changes in hematological and respiratory properties of muskrat (Ondatra zibethicus) blood // Canadian Journal of Zoology. Vol.62. No.4. P.537-545.

McNab B.K. 2008. An analysis of the factors that influence the level and scaling of mammalian BMR // Comparative Biochemistry and Physiology Part A: Molecular \& Integrative Physiology. Vol.151. P.5-28.
Moore J.W. 1966. Hemogram of the Chinese hamster // American Journal of Veterinary Research. Vol.27. P.608-610.

Musacchia X.J., Wilber C.G. \& Gorski T.W. 1955. Hematological studies on mammals from Alaska // Journal of Mammalogy. Vol.36. No.3. P.362-368.

Ostojic H., Cifuentes V. \& Monge C. 2002. Hemoglobin affinity in Andean rodents // Biological Research. Vol.35. No.1. P.27-30.

Panteleyev P.A. 2001. [Water Vole: Mode of the Species]. Moscow: Nauka. 527 p. [In Russian].

Patenaude R.P. \& Genest F.B. 1977. The hematology and chromosomes of the Canadian beaver (Castor canadensis) // Journal of Zoo Animal Medicine. Vol.8. P.6-9.

Promislow D.E.L. 1991. The evolution of mammalian blood parameters: Patterns and their interpretation // Physiological Zoology. Vol.64. P.393-431.

Puchalski W. \& Heldmaier G. 1986. Seasonal changes of heart weight and erythrocytes in the Djungarian hamster (Phodopus sungorus) // Comparative Biochemistry and Physiology. Part A: Comparative Physiology. Vol.84. No.2. P.259-263.

Ramírez-Muñoz M.P., Zúñiga G., Torres-Bugarín O., Portilla E., García-Martínez D., Ramos A., Cantú J.M. \& Sánchez-Corona J. 1999. Evaluation of the micronucleus test in peripheral blood erythrocytes by use of the splenectomized model // Comparative Medicine. Vol.49. P.418-420.

Reiderson T.H. 2010. Hematology of marine mammals // Weiss D.G. \& Wardrop K.J. (eds.). Schalm's Veterinary Hematology. Ames: Wiley-Blackwell. P.950-957.

Ruiz G., Rosenmann M. \& Cortes A. 2004. Thermal acclimation and seasonal variations of erythrocyte size in the Andean mouse Phyllotis xanthopygus rupestris // Comparative Biochemistry and Physiology Part A: Molecular \& Integrative Physiology. Vol.139. P.405-409.

Sabanova R.K. 2010. [The dependency to variability haemotological factors from ambience inhabitance timber mouse on North Caucasus] // Izvestiya Vysshikh Uchebnykh Zavedenii. Severo-Kavkazskii Region. Estestvennye Nauki. Vol.156. No.2. P.104-106 [In Russian].

Schmidt-Nielsen K. \& Knut S.N. 1984. Scaling: why is animal size so important? Cambridge: Cambridge University Press. 347 p.

Segal A.N. 1978. [Thermoregulation in coypu (Myocastor coypus) in summer] // Zoologicheskii Zhurnal. Vol.57. P.1878-1883 [in Russian].

Siegel A. \& Walton R.M. 2020. Hematology and biochemistry of small mammals // Carpenter J.W. (ed.). Ferrets, Rabbits, and Rodents. Elsevier Science. P.569-582.

Sokolov V.E., Lavrov N.P., Agadzhanyan A.K., Shiryaev V.V., Malygin V.M. \& Yacenko V.N. 1993. [Muskrat. Morphology, Systematics, Ecology]. Moscow: Nauka. 542 p. [in Russian].

Starostová Z., Konarzewski M., Kozłowski J. \& Kratochvíl L. 2013. Ontogeny of metabolic rate and red blood cell size in eyelid geckos: species follow different paths // PLoS ONE. Vol.8. No.5. e64715.

Tarakhtii E.A. \& Davydova Yu.A. 2007. Seasonal variation in hematological indices in bank vole (Clethrionomys glareolus) in different reproductive states // Biology Bulletin. Vol.34. P.9-19. 
Thomas A. \& Ono K. 2015. Diving related changes in the blood oxygen stores of rehabilitating harbor seal pups (Phoca vitulina) // PloS ONE. Vol.10. No.6. e0128930.

Turgeon M.L. 2004. Clinical Hematology: Theory and Procedure. Philadelphia: Lippincott Williams \& Wilkinson. $570 \mathrm{p}$.

Unruh K.D. 2018. Evaluating how behavioral, environmental and physiological factors have influenced the evolution of mammalian erythrocyte size. PhD Dissertation. Long Beach: California State University. 81 p.

Urison N.T. \& Buffenstein R. 1994. Kidney concentrating ability of a subterranean xeric rodent, the naked mole-rat (Heterocephalus glaber) // Journal of Comparative Physiology B. Vol.63. No.8. P.676-681.

Wauters L.A., Vermeulen M., Van Dongen S., Bertolino S., Molinari A., Tosi G. \& Matthysen E. 2007. Effects of spatio-temporal variation in food supply on red squirrel Sciurus vulgaris body size and body mass and its consequences for some fitness components // Ecography. Vol.30. P.51-65.

Wei D.B. \& Wei L. 2001. The mensuration results of the number of red cell and the content of hemoglobin and myoglobin in plateau zokor // Journal of Qinghai University. Vol.19. P.1-2.

Withers P.C. 1978. Models of diffusion-mediated gas exchange in animal burrows // The American Naturalist. Vol.12. P.1101-1112.
Wołk E. 1970. Erythrocytes, haemoglobin and haematocrit in the postnatal development of the root vole // Acta Theriologica. Vol.15. No.19. P.283-293.

Wołk E. 1985. Hematology of a hibernating rodent - the northern birch mouse // Acta Theriologica. Vol.30. No.22. P.337-348.

Wołk E. 1990. Physiological and ecological aspects of mammalian haematology in natural conditions // Centrum Doskonalenia Nauczycieli, Toruñ: P.1-150.

Wyckoff S.M. \& Frase B.A. 1990. Hematological adaptation to hypoxia in Peromyscus and Microtus at high and low altitude // Transactions of Illinois State Academy of Sciences. Vol.83. P.197-205.

Yemkuzheva M.M. 2013. [Comparative analysis of adaptive reactions of the blood system and interior signs of wildlife and synanthropic rodents (Muridae) to the conditions of the mountains of the central part of the Northern Caucasus]. PhD Thesis. Saratov. 19 p. [in Russian].

Zúñiga G., Torres-Bungarína O., Ramírez-Muñoza M.P., Ramos A., Fanti-Rodrígueze E., Portilla E., GarcíaMartínez D., Cantúc J.M., Gallegos-Arreolaa M.P. \& Sánchez-Coronaa J. 1996. Spontaneous micronuclei in peripheral blood erythrocytes from 35 mammalian species // Mutation Research/Genetic Toxicology. Vol.369. P.123-127. 